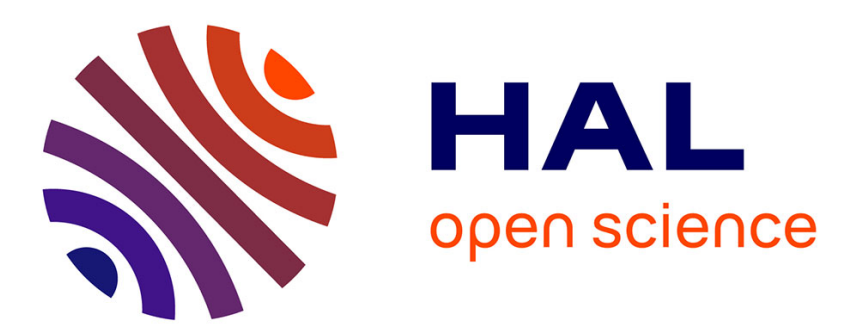

\title{
Food Preferences and Foraging Strategies of Wood-Feeding Termites in a West African Savanna
}

\author{
A. N'dri, J. Gignoux, S. Konaté
}

\section{To cite this version:}

A. N'dri, J. Gignoux, S. Konaté. Food Preferences and Foraging Strategies of Wood-Feeding Termites in a West African Savanna. Current Science, 2018, 114 (01), pp.186. 10.18520/cs/v114/i01/186-192 . hal-02388744

\section{HAL Id: hal-02388744 \\ https://cnrs.hal.science/hal-02388744}

Submitted on 26 May 2020

HAL is a multi-disciplinary open access archive for the deposit and dissemination of scientific research documents, whether they are published or not. The documents may come from teaching and research institutions in France or abroad, or from public or private research centers.
L'archive ouverte pluridisciplinaire HAL, est destinée au dépôt et à la diffusion de documents scientifiques de niveau recherche, publiés ou non, émanant des établissements d'enseignement et de recherche français ou étrangers, des laboratoires publics ou privés.

\section{(c)(1)}

Distributed under a Creative Commons Attribution| 4.0 International License 


\title{
Food preferences and foraging strategies of wood-feeding termites in a West African
}

\section{savanna}

\author{
A. B. N'Dri ${ }^{1, *}$, J. Gignoux ${ }^{2}$ and S. Konaté ${ }^{1}$ \\ ${ }^{1}$ UFR des Sciences de la Nature, Station d'Ecologie de Lamto/CRE, Pôle de Recherche Environnement et Développement Durable, \\ Université Nangui Abrogoua, 02 BP 801 Abidjan 02, Côte d'Ivoire \\ ${ }^{2}$ IEES-Paris (CNRS, IRD, UPMC, INRA, UPEC), UPMC, 4 place Jussieu, 75252 Paris cedex 05, France
}

\begin{abstract}
The feeding preferences of termites in a Guinean savanna (Lamto, Côte d'Ivoire) were studied in the field to better understand the incidence of termite damages observed on adult trees, which, on interaction with fire, affect the dynamics of the tree community. Two separate multiple-choice test experiments were conducted on the six dominant tree species, aiming at determining preferences for the species and for wood conditions naturally encountered and likely to affect termite consumption behaviour. The preferences of termites were determined by their occurrence on standard-sized wood pieces and their behaviour during the first attack. Two fungus-growing termites, Ancistrotermes and Microtermes were frequently encountered on wood pieces, whereas wood feeders were absent. The two genera have different preferences, and they do not compete for the same food. Wood density and water content did not explain termite preference. Holes in the bark seem to facilitate termite entry into pieces of wood, whereas the action of fire on wood apparently makes it less attractive to termites. In the field, the decision by termites to forage on a given tree species seems to be more driven by habitat and accessibility differences than real food quality differences.
\end{abstract}

Keywords: Food preference, foraging strategies, tree species, wood-feeding termites.

ABOUT 2600 species belonging to 281 genera of termites (Isoptera) have been described ${ }^{1}$. Termites are abundant in tropical ecosystems. They affect the decay of plants debris in soil, playing an important role in soil nutrients cycling and fertility ${ }^{2}$. Many species are known to move organic matter from the surface to deeper layers of the soil, improving and maintaining its porosity and aeration $^{3,4}$. Their negative impact on crops and houses is relatively well understood ${ }^{5-8}$. Recently, they have been proven to affect the mechanical resistance of living trees in fire-prone savanna ecosystems ${ }^{9}$, and the population dynamics of trees through their mortality rate ${ }^{10}$. It is therefore of key importance to understand what drives

*For correspondence. (e-mail: ndri.brigitte@yahoo.fr) termites towards feeding on and colonizing the trunks of particular tree species. Termite food preferences might, in the end, be responsible for the whole savanna physiognomy through their impacts on tree population dynamics, as suggested by Gould et al. ${ }^{11}$.

We tested the feeding preferences of termites through field experiments in order to understand their impact on the adult tree populations. Termites interact with fire to cause external openings on trees ${ }^{9}$. This has populationlevel consequences, trees with external openings reach smaller sizes both in height and basal diameter ${ }^{9}$. It also affects adult mortality of some dominant tree spe$\operatorname{cies}^{10}$. Although a plausible scenario of termite-fire interaction has been proposed, the precise mechanisms of interaction are unknown. In particular, we do not know which are the termite genera responsible for the impacts observed on trees; which tree species are more suitable for termites; how are trees entered, and in particular, whether holes caused by fire on trees allow termites to enter them. Our experiments address these questions. Experiment 1 was a multiple-choice test designed to test relative preferences among tree species, whereas experiment 2 was a multiple-choice test designed to test relative preferences among five different wood conditions. In order to better understand the tree-termite interactions, we identified (1) termite genera responsible for tree damage, (2) tree species more suitable to termites and (3) condition of the wood preferred by termites.

\section{Materials and methods}

\section{Study site}

The experiments were conducted at the Lamto Research Station in Côte d'Ivoire $\left(6^{\circ} 13^{\prime} \mathrm{N}, 5^{\circ} 02^{\prime} \mathrm{W}\right)$. The major tree species are shrubby and usually $<10 \mathrm{~m}$, high, and more than $90 \%$ of the woody layer is composed of four species: Bridelia ferruginea Benth. (Phyllantaceae), Crossopteryx febrifuga (Afzel. ex G. Don) Benth. (Rubiaceae), Cussonia barteri A. Rich. (Araliaceae), and Piliostigma thonningii (Schum.) Milne-Redhead (Caesalpiniaceae) ${ }^{12}$. Shoots of woody species such as Annona senengalensis 
Pers. (Annonaceae) grow in the grass layer, whereas in the upper stratum we find Terminalia schimperiana Hochst. (Combretaceae).

With biomass reaching 3.4-19.6 $\mathrm{g} \mathrm{m}^{-2}$ (fresh weight), termites are one of the major animal components of the Lamto ecosystem ${ }^{13,14}$. The main trophic groups are the fungus-growing (from 1.15 to $5.93 \mathrm{~g} \mathrm{~m}^{-2}$ ), humivorous (from 2.14 to $11.65 \mathrm{~g} \mathrm{~m}^{-2}$ ), and xylophageous and grassforaging (from 0.17 to $1.98 \mathrm{~g} \mathrm{~m}^{-2}$ ) termites ${ }^{14-16}$. Their activities result in the formation of biogenic structures which are frequently encountered in all savanna types ${ }^{17}$ : above-ground termitaria; below-ground nests; comb chambers; sheetings and galleries. The latter two are built by workers, generally using soil-impregnated saliva covering the food supply or termite pathway. Also, termite mounds which are very large, complex biogenic structures grouping below-ground nests of different termite species, are frequently encountered in all savanna types ${ }^{13,18}$. All Lamto savannas are subject to annual fires ${ }^{19,20}$. Termites, which are known to consume only dead material ${ }^{21}$, have recently been observed to use the burned parts of trees to enter the trunk ${ }^{9}$. Experiments were conducted in two burned shrubby savanna habitats (the most frequent savanna type in Lamto), replicated twice in each area. Experimental plots were selected as far as possible from termite mounds, nests and trees, which could bias the sampling because they favour the presence of one species of termite.

\section{Termite sampling methods on experimental plots}

To estimate the overall termite diversity of an experimental habitat, the whole experimental plot was searched for termites. A modified standardized method of the protocol for rapid assessment of termite diversity by Jones and Eggleton $^{22}$ was used ${ }^{9}$. Sampled termites were identified to the genus level using standard determination keys ${ }^{23-26}$ and species descriptions $^{27}$. Following Josens ${ }^{15}$, Deligne ${ }^{28}$ and Sands ${ }^{29}$, they were classified into fungus-growers, soil-feeders, wood-feeders and grass-feeders. Wood-feeders and fungusgrowers were expected to be actively feeding on wood.

\section{Tree species and experimental procedures}

A total of six dominant tree species of the Lamto reserve were used as potential food for termites: A. senegalensis; B. ferruginea; C. febrifuga; Cussonia arborea; P. thonningii and T. schimperiana.

Five wood blocks ( $10 \mathrm{~cm}$ in length) were cut from living (around $6 \mathrm{~cm} \mathrm{dia)} \mathrm{branches} \mathrm{of} \mathrm{each} \mathrm{of} \mathrm{the} \mathrm{six} \mathrm{spe-}$ cies and additional treatments were applied to the blocks to mimic the possible conditions of wood debris that could be encountered by termites in the field. The fresh wood with holes $(\mathrm{FH})$ was obtained by making holes with nails through the bark of wood blocks to simulate the holes left by fire and broken branches on the living trees as a test of the 'access point' hypothesis ${ }^{30,31}$, as observed in N'Dri et al. ${ }^{9}$. According to N'Dri et al. ${ }^{9}$, termites are better able to consume parts of trees impacted by fire than fresh ones and use them to get into the trees. These observations were tested using burned (B) and charred (C) pieces of wood in order to simulate the impact of fire on living trees. To standardize their water content, the dry, burned and charred wood blocks were oven-dried at $100^{\circ} \mathrm{C}$ for $72 \mathrm{~h}$. Burned and charred treatment was obtained by placing blocks in dry grass (cropped in the field and drying) fires, until char appeared on the block surface for ' $\mathrm{C}$ ' and less than $2 \mathrm{~min}$, for ' $\mathrm{B}$ ', according to the description of savanna fire behaviour in the literature ${ }^{32-34}$. Dry wood (D) was added to test whether dead wood was preferred over fresh $(\mathrm{F})$ wood by termites, as suggested by Josens ${ }^{15}$ and Grassé ${ }^{35}$. All the wood blocks (FH, B, C, $\mathrm{D}, \mathrm{F})$ were tagged and placed on each of the two plots.

Our first experiment focused on termite preference for wood of a particular tree species (species preference test, SPT). Wood blocks of the six species in the same condition were grouped at one field location, directly on the soil and $10 \mathrm{~cm}$ apart (distance chosen to give the same probability for a wood block to be consumed by foraging termites) from each other. Five groups of wood blocks, one for each wood condition, were randomly placed $35 \mathrm{~m}$ apart from each other, which corresponds to the approximate range of termite prospection (S.K., pers. commun.). The second experiment focused on termite preference for a particular wood condition (condition preference test, CPT). It was setup like the first experiment, but reversing the role of species and wood conditions. Each of these experiments was replicated twice in each shrubby savanna (four replicates overall).

Wood blocks were visited daily for termite impacts, to determine the attack order of different tree species. A block was considered impacted by termites when it was covered by biogenic structures (sheetings or/and tunnelgalleries). Biogenic structure type (gallery or sheeting) was recorded to determine the use of wood blocks by termites, tunnel-galleries being built for prospection and sheetings for feeding ${ }^{36}$. When termite attacks were found on all wood blocks, observations were done every second week from April 2009 to January 2010. F and FH wood blocks were changed at each sample. Termites and their biogenic structures were systematically searched in order to determine the termite genera. When termites were found, representative $(\sim 10)$ individuals of the soldier caste and/or worker were collected and preserved in $75 \%$ alcohol and later identified to the genus level.

\section{Measurement of wood species density}

According to Behr et $a l^{37}$, termites preferentially consume lower density wood. To test this, we estimated the 


\section{RESEARCH ARTICLES}

wood density of five of the dominant tree species of the Lamto reserve (B. ferruginea, C. febrifuga, C. arborea, $P$. thonningii and $T$. shimperiana) in two different conditions (fresh and dry). One wood block was cut from living branches of five different trees for each species, then each wood block was weighed and its volume determined by immersion in water in a 1 litre beaker graduated to the nearest cubic centimetre, density being then obtained as the ratio of sample mass over its volume. The average humidity content of each wood species was determined simultaneously by weighing the samples after ovendrying at $100^{\circ} \mathrm{C}$ during $72 \mathrm{~h}$. The impact of average water content of each tree species on the feeding preference of termite genera was then tested.

\section{Statistical analyses}

All analyses were performed using the $\mathrm{R}$ software (http://www.r-project.org/). The distribution of different termite genera on wood blocks, and of sheetings and galleries on wood blocks during the first termite attack were compared using $\chi^{2}$ tests. Linear models (LM) with logit transformation were used to analyse the effect of tree species, wood condition and experiment design on: (1) the feeding preference of two termite genera (i.e. Ancistrotermes and Microtermes) and (2) the occurrence of biogenic structures (galleries and sheetings) on tree species and wood condition during the first attack. Linear models were also used for analysing the wood humidity and density according to wood species and condition. Post-hoc Tukey's HSD test was used to identify (1) the more preferred tree species and wood condition by termites and (2) the wood block conditions and species presenting the highest density and humidity. Generalized linear models (GLM) were used for analysing the occurrence of biogenic structures during the first attack.

\section{Results}

\section{Termite diversity in the study site}

At the experiment sites, 10 termite genera distributed into four functional groups were collected. Five fungusgrowers (Ancistrotermes, Macrotermes, Microtermes, Pseudacanthotermes and Odontotermes), two soil-feeders (Adaiphrotermes and Amitermes), two wood-feeders (Microcerotermes and Fulleritermes) and one grassfeeder (Trinervitermes) were found.

\section{Termite genera on the wood baits}

Ancistrotermes and Microtermes were the only genera frequently found on wood blocks for statistical analyses to be performed (Figure 1). The occurrence of termites on wood blocks significantly differed with termite genus $\left(\chi^{2}=5530.69, \mathrm{~d} f=7, P<0.001\right)$.

\section{Ancistrotermes and Microtermes feeding}

The occurrence of termites on different tree species changed according to their genera (ANOVA, $F_{1,10}=$ 45.61; $P<0.001$; Figure 2).

Occurrence of the Ancistrotermes on wood blocks varied according to tree species (ANOVA with logit transformation, $\left.F_{5,60}=4.91 ; P=0.001\right)$. No experiment-type

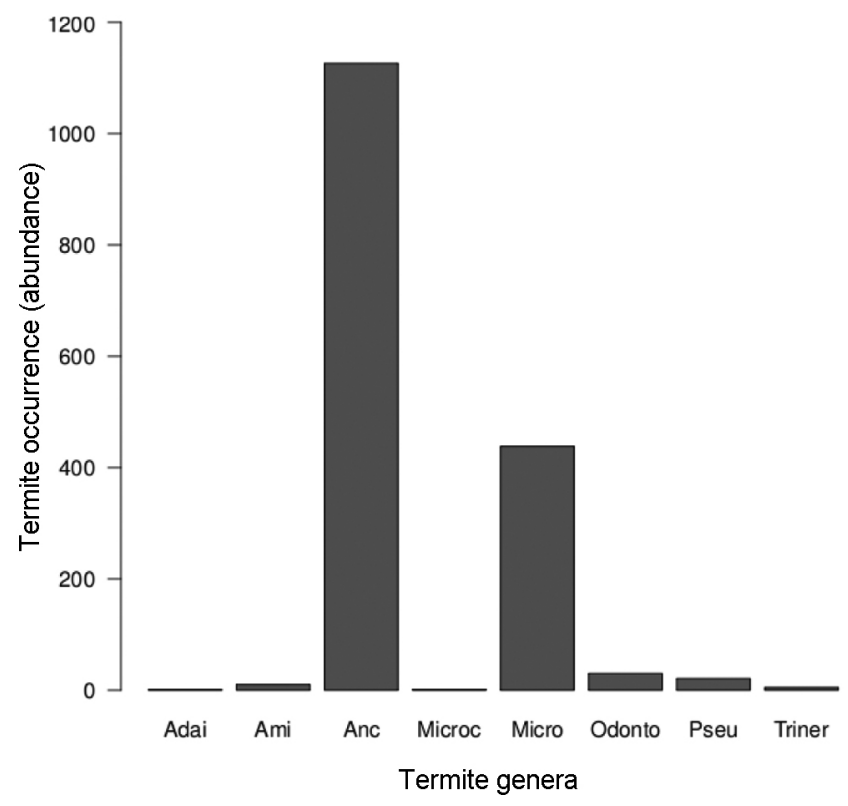

Figure 1. Occurrence of different termite genera on wood blocks. Adai, Adaiphrotermes; Ami, Amitermes; Anc, Ancistrotermes; Microc, Microcerotermes; Micro, Microtermes; Odonto, Odontotermes; Pseu, Pseudacanthotermes and Triner, Trinervitermes.

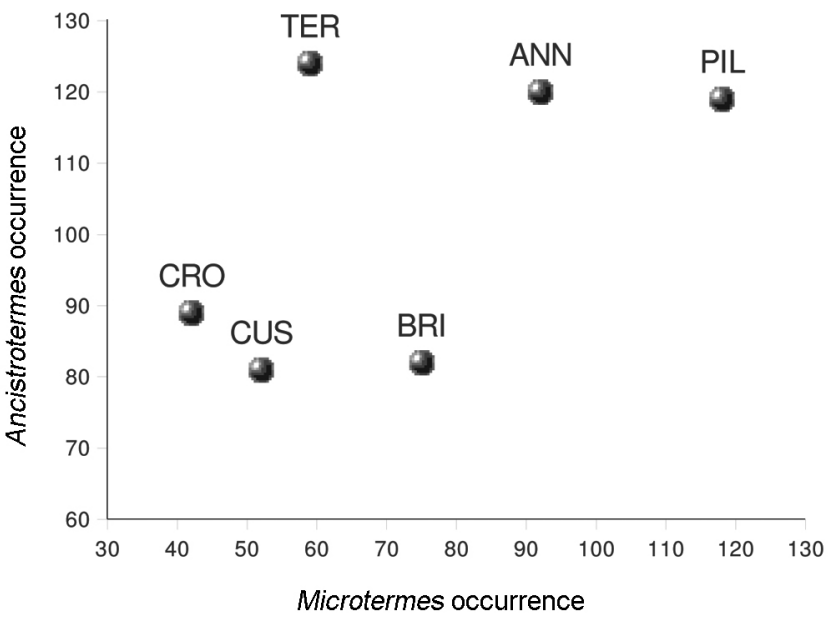

Figure 2. Absence of competition between Ancistrotermes and Microtermes for tree species preferences. ANN, Annona senegalensis; BRI, Bridelia ferruginea; CRO, Crossopteryx febrifuga; CUS, Cussonia arborea; PIL, Piliostigma thonningii and TER, Terminalia schimperiana. 
effect was observed on their occurrence (ANOVA with logit transformation, $\left.F_{1,60}=1.40 ; P=0.24\right)$. The most preferred wood species was $T$. schimperiana and the least preferred was $B$. ferruginea (Figure 3).

The occurrence of Microtermes also varied with tree species (ANOVA with logit transformation, $F_{5,180}=8.61$; $P<0.001)$; the most preferred species was $P$. thonningii and the least preferred were C. febrifuga and $C$. arborea (Figure 3). Experiment type did not influence Microtermes consumption (ANOVA with logit transformation, $\left.F_{1,180}=0.007 ; P=0.93\right)$.

The interaction between wood condition and experiment type was statistically significant (ANOVA with logit transformation, $\left.F_{4,180}=4.35 ; P=0.002\right)$. When individuals of Microtermes had to choose between several wood conditions (CPT), fresh wood with holes (FH) was the most preferred and the least preferred was charred wood (C; ANOVA with logit transformation, $F_{4,15}=3.86$; $P=0.024$, post hoc Tukey's HSD test, $95 \%$ confidence interval; Figure 4).

\section{Foraging behaviour of termites according to tree species and wood condition}

The occurrence of galleries and sheetings during the first attack of termites changed according to experiment type (ANOVA with logit transformation, $F_{1,117}=5.24$; $P=0.02$ ). The occurrence of this biogenic structure changed significantly according to tree species in SPT (binomial GLM model with logit link; deviance $=12.95$, $\mathrm{d} f=5, \chi^{2}=136.53, P=0.023$, Figure 5). In addition, more sheetings $(67 \%)$ were built than galleries $(33 \%)$ during the first attack of termites in SPT $\left(\chi^{2}=13, \mathrm{~d} f=1\right.$, $P \leq 0.001)$.

CPT did not reveal any termite preference for a specific wood condition during the first attack. No significant difference was noted on the occurrence of sheetings and galleries (binomial GLM model with logit link; deviance $=3.055, \mathrm{~d} f=4, \chi^{2}=159.38, P=0.55$; Figure 5). Termites built nearly as many galleries $(46 \%)$ as sheetings (54\%) during their first attack $\left(\chi^{2}=0.68, \mathrm{~d} f=1, P=0.41\right)$.

\section{Wood density and humidity per species}

Wood block density varied with tree species and condition (ANOVA, $\mathrm{F}_{4,40}=14.53 ; P<0.001$ and $\mathrm{F}_{3,40}=$ 118.28; $P<0.001)$. Highest densities were observed in dry woods of $C$. febrifuga, B. ferruginea $P$. thonningii and $T$. schimperiana, whereas $C$. arborea presented the lowest value. Intermediate density was observed in fresh woods of $T$. schimperiana (Figure 6). Wood humidity averaged $\sim 30 \%$, but varied according to species (ANOVA, $\left.\mathrm{F}_{4,20}=3.12 ; P=0.04\right)$. C. arborea presented the highest water content, whereas $B$. ferruginea presented the lowest value (Figure 7).

\section{Discussion}

Among the eight termite genera collected in this work, only Ancistrotermes and Microtermes were significantly abundant. As wood-feeders were frequently found in living trees ${ }^{9}$, we expected to collect more of them on wood

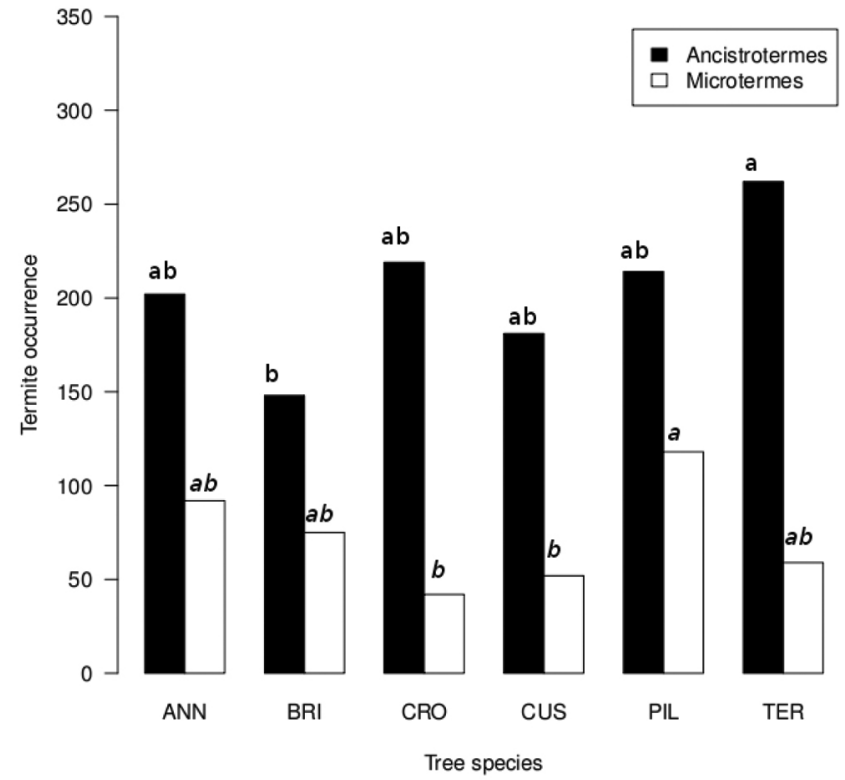

Figure 3. Tree species preferences of Ancistrotermes and Microtermes. Letters indicate groups of non-significantly different values at the $95 \%$ level according to per-termite genus Tukey's HSD post-hoc tests. Species codes as in Figure 2.

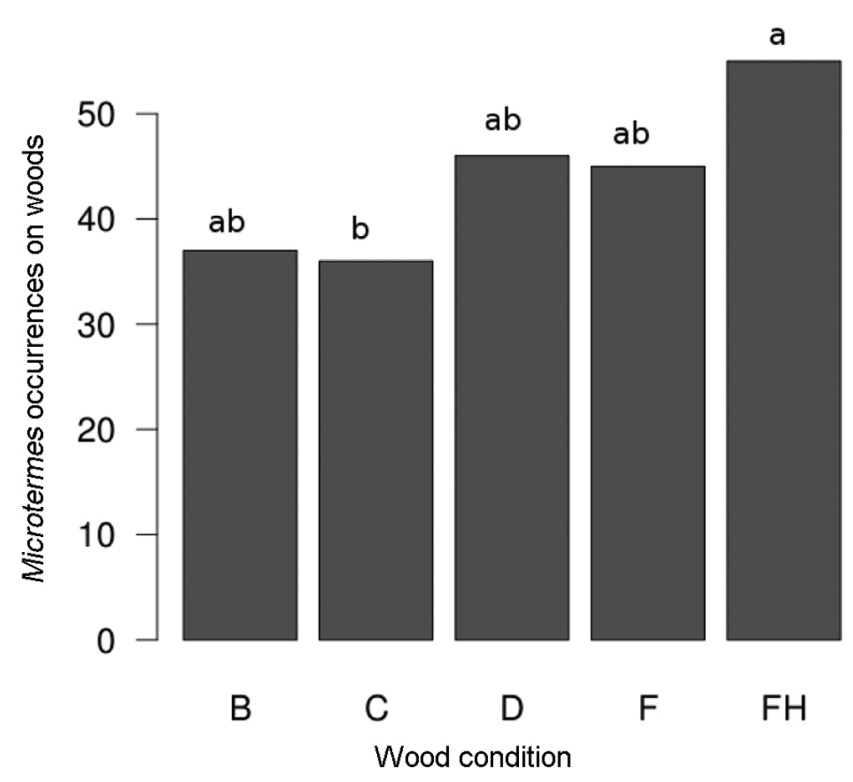

Figure 4. Microtermes preferences in the wood condition preference test. Letters indicate groups of non-significantly different values at the 95\% level according to Tukey's HSD post-hoc tests. B, Burned; C, Charred; D, Dry; F, Fresh; FH, Fresh with holes. 
blocks, but found fungus-growing termites instead, as observed by $\mathrm{Basu}^{38}$ in Lamto on food preference of fungus-growing termites. Fungus-growers (Termitidae: Macrotermitinae) need plant material for the establishment of their fungus combs, known as the substratum of their symbiotic fungi ${ }^{39}$. In addition, termites of these two genera have been classified as pests in many studies in human-managed ecosystems ${ }^{40-43}$ and naturals ones ${ }^{44}$. Together with the fact that Ancistrotermes and Microtermes are known as the most common fungus-growing termites $^{15,38,44}$ in Lamto, their habit of digging galleries into living trees was also revealed in natural ecosystems $9,15,45,46$

The absence of wood-feeders on wood samples could be due to the preference for higher quantity of wood found on a whole tree: wood-feeders often build arboreal nests on living trees ${ }^{9,47}$ and would therefore preferably exploit the trees they live on rather than risk exploration in the open to search for smaller wood quantities. For wood-feeders, wood is not only a food, but also a habitat.

As suggested by Stewart and Zalucki ${ }^{48}$, aggregation or occurrence on different wood blocks was used as a measure of preference. The ability of termites to be attracted by one wood species or condition during their first attack was also used to measure preference.

The occurrence of termites on wood samples changed according to tree species. They also built directly more feeding sheetings than prospection galleries on wood during their first attack when presented with different wood
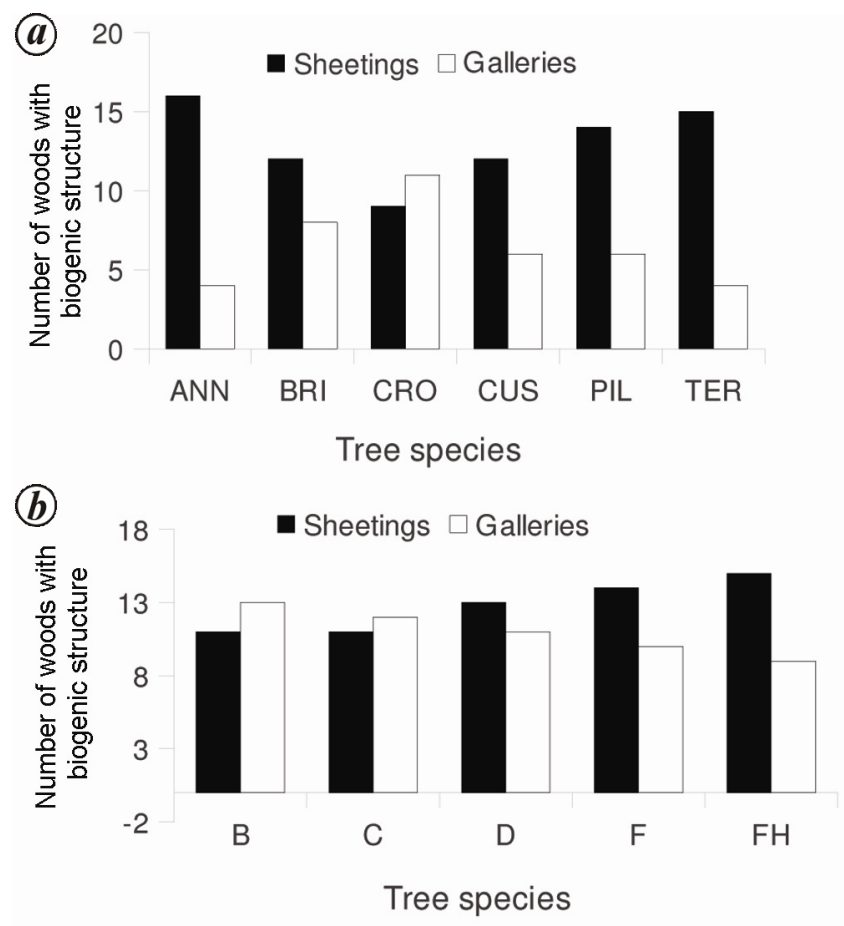

Figure 5. Biogenic structures build by termites on wood during the first attack on (a) SPT and (b) CPT. Species and wood conditions codes as in Figures 2 and 4. species, suggesting that the termites are able to choose their food. Indeed, food preference of termites has been reported in several studies ${ }^{38,49-51}$.

Among the many factors which could explain this preference of termites, we tested a possible effect of wood density and wood average humidity. Inta et al. $^{49}$ studied the material properties on termite food choice. According to Behr et al. ${ }^{37}$, termites prefer lower density wood because wood density affects the fragmentation process by termites ${ }^{52}$. According to our density measurements, wood densities were remarkably similar among species, except for $C$. arborea which had low density and high water content. The uniformity in density prevents any explanation of preferences based on this factor alone.

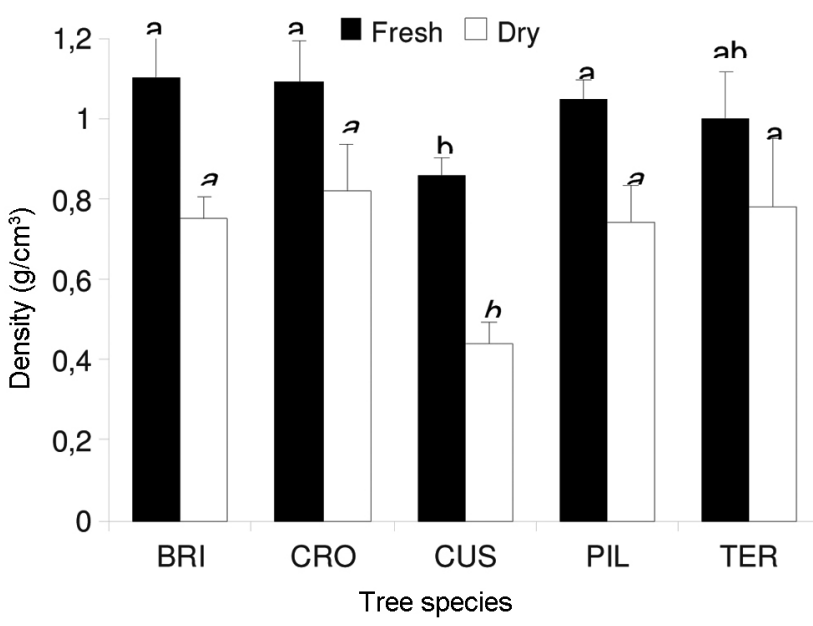

Figure 6. Density according to wood species and condition. Species codes as in Figure 2. Letters indicate groups of non-significantly different values at the $95 \%$ level according to per-wood density Tukey's HSD post-hoc tests.

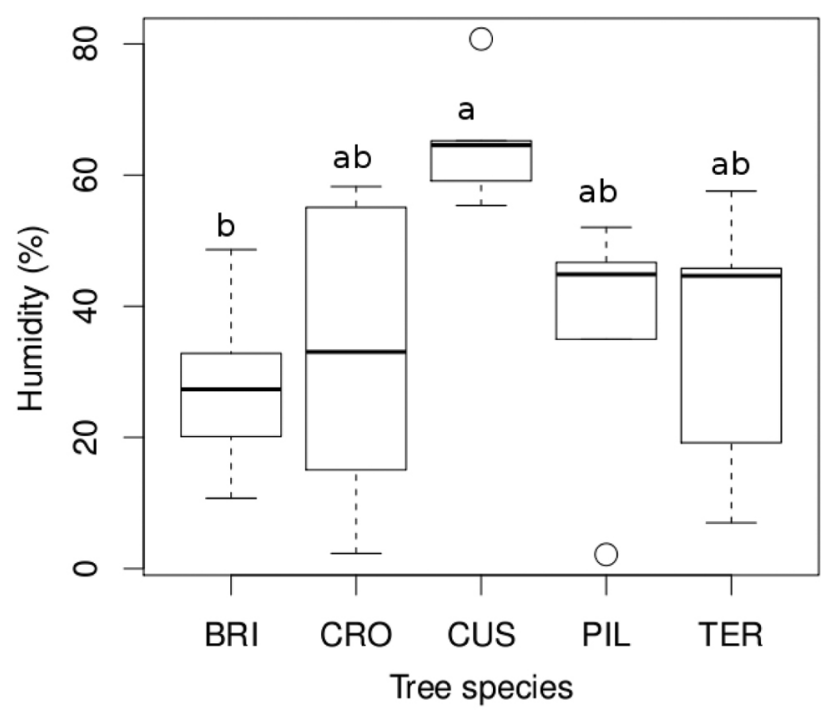

Figure 7. Water content of different wood species. Species codes as in Figure 2. Letters indicate groups of non-significantly different values at the $95 \%$ level according to per-wood humidity Tukey's HSD posthoc tests.

CURRENT SCIENCE, VOL. 114, NO. 1, 10 JANUARY 2018 
Termite foraging has been shown to depend on moisture in some cases ${ }^{53,54}$. As in case of humidity, the pattern of variations of wood humidity did not match the preferences of the studied termite genera (Figure 7). According to Wong and Lee ${ }^{55}$, several factors could explain the food preference of termites. In a laboratory experiment, these authors studied up to ten factors to explain the feeding behaviour of Micorcerotermes crassus. In field experiments, many other factors could further complicate the patterns. Any tree species did not seem attractive for termites since they did not compete for the same tree species.

Fresh wood with holes was preferred by termites than the other wood conditions, probably due to the fact that holes constitute easy entry points into the wood ${ }^{9}$. Charred wood blocks were the least preferred, suggesting that the positive effect of fire on termite trunk-digging activity is more related to the creation of entry points and exposure of dead wood by fire than by an improvement in food quality.

Food preferences at the wood block level did not match observations on adult trees 9 . These authors ${ }^{9}$ observed that C. febrifuga was a preferred target for termites, most individuals of this species being entirely piped, while in the present study $T$. schimperiana and $P$. thonningii were the two most preferred species. However, N'Dri et al. ${ }^{10}$ have observed that $P$. thonningii (more preferred in this field experiment) suffered a higher mortality as a result of termite and fire impact.

Our results show that (1) wood-feeders are not interested in small pieces of wood, while fungus-growers are; (2) the two different genera studied have different preferences, but they do not seem to compete for the same food; (3) neither wood density nor water content is correlated with preferences; (4) holes in the bark seem to facilitate termite entry into pieces of wood; (5) the action of fire on wood apparently makes it less attractive to termites. These results tend to show that, in the field, the decision of termites to forage on a given tree species is driven by habitat and accessibility differences (points (1) and (4)) than real food quality differences (point (3)). From points (4) and (5) above, it is clear that fire improves the access of termites to dead wood, but that its direct effect on wood (charring and probably hardening) makes it less attractive to termites, thus confirming the hypothesis of N'Dri et al. ${ }^{9}$.

1. Kambhampati, S. and Eggleton, P., Taxonomy and phylogeny of termites. In Termites: Evolution, Sociality, Symbioses, Ecology (eds Abe, T., Bignell, D. E. and Higashi, M.), Kluwer Academic Publishers, Amsterdam, The Netherlands, 2000, pp. 1-23.

2. Bignell, D. and Eggleton, P., Termites in ecosystems. In Termites: Evolution, Sociality, Symbioses, Ecology (eds Abe, T., Bignell, D. E. and Higashi, M.), Kluwer Academic Publishers, Amsterdam, The Netherlands, 2000, pp. 363-387.

3. Garnier-Sillam, S. and Harry, M., Distribution of humic compounds in mounds of some soil-feeding termite species of tropical rainforests: its influence on soil structure stability. Insect. Soc., 1995, 42, 167-185.
4. Lavelle, P. et al., Soil function in a changing world: the role of invertebrate ecosystems engineers. Eur. J. Soil Biol., 1997, 33, 159-193.

5. Akpesse, A., Kouassi, P. K., Tano, Y. and Lepage, M., Impact des termites dans les champs paysans de riz et de maïs en savane sub-soudanienne (Booro Borotou, Côte-d'Ivoire). Sci. Nat., 2008, 5, 121-131.

6. Constantino, R., The pest termites of South America: taxonomy, distribution and status. J. Appl. Entomol., 2002, 126, 355-365.

7. Fowler, H. G. and Forti, L. C., Status and prospects of termite problems and control in Brazil. Sociobiology, 1990, 17, 45-56.

8. Han, S. H., Dégâts causés par les termites sur les bâtiments dans la région de Dakar au sénégal. Actes Coll. Insect. Soc., 2000, 13, 6164.

9. N’Dri, A. B., Gignoux, J., Konaté, S., Dembélé, A. and Aïdara, D., Origin of trunk damage in West African savanna trees: the interaction of fire and termites. J. Trop. Ecol., 2011, 27, 269-278.

10. N'Dri, A. B., Gignoux, J., Konaté, S. and Aïdara, D., The dynamics of hollowing in annually burnt savanna trees and its effect on adult tree mortality. Plant Ecol., 2014, 215, 27-37.

11. Gould, M. S., Lowe, A. J. and Clarke, G. P., The frequency of termite (Isoptera) Damage to tree species in Namakutwa forest, Tanzania. Sociobiology, 1993, 23, 189-198.

12. Menaut, J. C. and César, J., Structure and primary productivity of Lamto savannas (Ivory Coast). Ecology, 1979, 60, 1197-1210.

13. Abbadie, L., Lepage, M. and Le Roux, X., Soil fauna at the forestsavanna boundary: role of termite mounds in nutrient cycling. In Nature and Dynamics of Forest-Savanna Boundaries (eds Furley, P. A., Proctor, J. and Ratter, J. A.), Chapman and Hall, London, UK, 1992, pp. 473-484.

14. Konaté, S., Le Roux, X., Verdier, D. and Lepage, M., Effect of underground fungus-growing termites on carbon dioxide emission from soils at the chamber- and landscape-scales in an African savanna. Funct. Ecol., 2003, 17, 305-314.

15. Josens, G., Etudes biologiques et ecologiques des termites (Isoptera) de la savane de Lamto. Thèse de doctorat de l'Université Libre de Bruxelles, 1972.

16. Yapi, A., Biologie écologie et métabolisme digestif de quelques espèces de termites humivores de savane. Thèse de 3ème cycle, Université d'Abidjan, Abidjan, 1991.

17. Lepage, M., Abbadie, L., Josens, G., Konaté, S. and Lavelle, P., Perturbations of soil carbon dynamics by soil fauna. In Lamto: Structure, Functioning and Dynamics of a Savanna Ecosystem (eds Abbadie, L. et al.), Springer Verlag, New York, USA, 2006, pp. 235-251.

18. Konaté, S., Le Roux, X., Tessier, D. and Lepage, M., Influence of large termitaria on soil characteristics, soil water regime, and tree leaf shedding pattern in a West African savanna. Plant Soil, 1999, 206, 47-60.

19. Gautier, L., Contact forêt-savane en Côte d'Ivoire centrale: évolution du recouvrement ligneux des savanes de la réserve de Lamto (sud du V baoulé). Candollea, 1990, 45, 627-641.

20. Mordelet, P. and Menaut, J. C., Influence of trees on aboveground production dynamics of grasses in a humid savanna. J. Veg. Sci., 1995, 6, 223-228.

21. Josens, G., Etudes biolgique et écologique des termites (Isoptera) de la savane de Lamto Pakobo (Côte-d'Ivoire), volume 42 of Mémoires de la classe des sciences, Serie 2. Académie royale de Belgique, Bruxelle, 1977.

22. Jones, D. T. and Eggleton, P., Sampling termite assemblages in tropical forests: testing a rapid biodiversity assessment protocol. J. Appl. Ecol., 2000, 37, 191-203.

23. Bouillon, A. and Mathot, G., Quel est ce termite Africain? Université de Léopoldville, Léopoldville, 1965.

24. Bouillon, A. and Mathot, G., Quel est ce termite africain? Supplément $N^{\circ} 1$. Université de Lovanium, Kinshassa, 1966. 


\section{RESEARCH ARTICLES}

25. Bouillon, A. and Mathot, G., Quel est ce termite africain? Supplément $\mathrm{N}^{\circ}$ 2. Université Nationale du Zaïre, Kinshassa, 1971.

26. Webb, G. C., Keys of the Genera of the African Termites Adapted from Revision Der Termiten Afrikas of Sjoestedt, Ibadan University Press, Ibadan, Nigeria, 1961.

27. Grassé, P. P., Comportement, sociabilité, écologie, évolution, systématique. Termitologia. Tome III. Masson, Paris, 1986.

28. Deligne, J., Caractères adaptatifs au régime alimentaire dans la mandibule des termites (Insectes Isoptères). CR Acad. Sci. Paris, 1966, 263, 1323-1325.

29. Sands, W. A., The Identification of Worker Castes of Termite Genera from Soils of Africa and the Middle East, CAB International, New York, USA, 1998.

30. Whitford, K. R., Hollows in jarrah (Eucalyptus marginata) and marri (Corymbia calophylla) trees. I. Hollow sizes, tree attributes and ages. For. Ecol. Manage., 2002, 160, 201-214.

31. Whitford, K. D. and Williams, M. R., Hollows in jarrah (Eucalyptus marginata) and marri (Corymbia calophylla) trees. II. Selecting trees to retain for hollow dependent fauna. For. Ecol. Manage., 2002, 160, 215-232.

32. Monnier, Y., Les effects des feux de brousse sur une savane préforestière de Côte d'Ivoire. Etud. Eburnéennes, 1968, 9, 1-260.

33. Stronach, N. R. H. and MacNaughton, S. J., Grassland fire dynamics in the Serengeti ecosystem, and a potential method of retrospectively estimating fire energy. J. Appl. Ecol., 1989, 26, 10251033.

34. Miranda, A. C., Miranda, H. S., Dias, I. O. and Souza, B. D. F., Soil and air temperatures during prescribed cerrado fires in Central Brazil. J. Trop. Ecol., 9, 1993, 313-320.

35. Grassé, P. P., Recherche sur la systématique et la biologie des termites de 1'Afrique Occidentale Française. Première partie, Protermitidae, Mesotermitidae, Metatermitidae (Termitinae). Ann. Soc. Entomol. Fr., 1937, 106, 1-100.

36. Mora, P., Seugea, C., Rossib, J. P. and Roulanda, C., Abundance of biogenic structures of earthworms and termites in a mango orchard. Eur. J. Soil Biol., 2006, 42, S250-S253.

37. Behr, E. A., Behr, C. T. and Wilson, L. F., Influence of wood hardness on feeding by the Eastern subterranean termite, Reticulitermes flavipes (Isoptera: Rhinotermitidae). Ann. Entomol. Soc. Am., 1972, 65, 457-460.

38. Basu, P., Food preference and interspecific interactions in fungusgrowing termite assemblage in a West African savanna. Curr. Sci., 2011, 100(1), 77-83.

39. Lepage, M., Abbadie, L. and Mariotti, A., Food habits of sympatric termite species (Isoptera, Macrotermitinae) as determined by stable carbon isotope analysis in a Guinean savanna (Lamto, Côte d'Ivoire). J. Trop. Ecol., 1993, 9, 303-311.

40. Mitchell, J. D., Termites as pests of crops, forestry, rangeland and structures in southern Africa and their control. Sociobiology, 2002, 40, 47-69.

41. Pearce, J. W., Logan, J. W. M. and Tiben, A., Termites (Isoptera) from the Darfur region of the Sudan with comments on their pest status. J. Arid Environ., 1995, 30, 197-206.

42. Rajagopal, D., Economically important termite species in India. Sociobiology, 2002, 40, 33-46.

43. Rouland-Lefèvre, C. and Mora, P., Control of Ancistrotermes guineensis Silvestri (Termitidae: Macrotermitinae), a pest of sugarcane in Chad. Int. J. Pest Manage., 2002, 48, 81-86.

44. Dosso, K., Konaté, S., Aidara, D. and Linsenmair, K. E., Termite diversity and abundance across fire-induced habitat variability in a tropical moist savanna (Lamto, Central Côte d'Ivoire). J. Trop. Ecol., 2010, 26, 323-334.

45. Garcia, C., Les termites champigonnistes de Lamto: structure du peuplement et compétition interspécifique, DEA d'Ecologie, Université Paris 6, 1996.

46. Konaté, S., Structure, dynamique et rôle des buttes termitiques dans le fonctionnement d'une savane préforestière (Lamto, Côte d'Ivoire): le termite champignoniste Odontotermes comme ingénieur de l'écosystème. Thèse de doctorat de l'Université de Paris 6, France, 1998.

47. Werner, P. A. and Prior, L. D. Tree-piping termites and growth and survival of host trees in savanna woodland of north Australia. J. Trop. Ecol., 2007, 23, 611-622.

48. Stewart, A. D. and Zalucki, M. P., Polyethism and comparability of termite choice assays in a model system using Microcerotermes turneri (Termitinae: Termitinae): implications for standardised testing techniques. Sociobilogy, 2006, 48, 741-758.

49. Inta, R., Evans, T. A., Lai, J. C. S. and Lenz, M., What do vibrations have to do with termites' food choice? Acoustics Australia, 2007, 35, 73-108.

50. Ngee, P. S., Tashiro, A., Yoshimura, T., Jaal, Z. and Lee, C. Y., Wood preference of selected Malaysian subterranean termites (Isoptera: Rhinotermitidae, Termitidae). Sociobiology, 2004, 43, 535-550.

51. Waller, D. A, Jones, C. G. and La Fage, J. P., Measuring wood preference in termites. Entomol. Exp. Appl., 1990, 56, 117-123.

52. Bultman, J. D., Beal, R. H. and Ampong, F. F. K., Natural resistance of tropical African woods to Coptotermes formosanus Shiraki. For. Prod. J., 1979, 29, 46-51.

53. Delaplane, K. S. and La Fage, J. P., Preference for moist wood by the Formosan subterranean termite (Isoptera: Rhinotermitidae). J. Econ. Entomol., 1989, 82, 95-100.

54. Green, J. M., Scharf, M. E. and Bennett, G. W., Impacts of soil moisture level on consumption and movement of three sympatric subterranean termites (Isoptera: Rhinotermitidae) in a laboratory assay. J. Econ. Entomol., 2005, 98, 933-937.

55. Wong, N. and Lee, C., Influence of different substrate moistures on wood consumption and movement patterns of Microcerotermes crassus and Coptotermes gestroi (Blattodea: Termitidae, Rhinotermitidae). J. Econ. Entomol., 2010, 103, 437-442.

ACKNOWLEDGEMENTS. We thank Sébastien Barot for comments on the manuscript. This work was supported by RIPIECSA-Côte d'Ivoire Project (Recherche Interdisciplianaire et Participative sur les Interactions entre les Ecosystèmes, le Climat et les Sociétés en Afrique de l'Ouest). A.B.N'.D. thanks the BDI fellowship programme of CNRS (Centre National de la Recherche Scientifique) for scholarship. We thank François N'Guessan, Honoré Kounan, Hubert Kouadio Kouakou, Alexis N'DRI, Bruno Brou, Drissa Coulibaly, Issa Quattara for support, and technical staff of Lamto Reserve, for assistance during field experiments.

Received 6 June 2016; accepted 12 July 2017

doi: $10.18520 / \mathrm{cs} / \mathrm{v} 114 / \mathrm{i} 01 / 186-192$ 